\title{
STUDI ORIENTALIS TERHADAP ISLAM: DORONGAN DAN TUJUAN
}

\author{
Oleh: \\ Syukri Al fauzi Harlis Yurnalis \\ Tenaga Pengajar Aqidah dan Filsafat Islam UIN IB \\ Syukrialfauzi@uinib.ac.id
}

\begin{abstract}
Abstrak
Orient dalam bahasa Prancis dan mustasyriq dalam bahasa arabnya, dan kita mengenalnya dengan istilah orientalis, suatu istilah yang sudah begitu dekat dengan telinga dunia akademisi. Studi orientalis terus mengalami perkembangannya dari masa kemasa, dengan berbagai macam dinamika yang terus berkembang. Tidak henti-hentinya dunia Barat meneliti tentang segala aspek yang berhubungan dengan ke-Timuran. Tentunya hal ini juga menjadi perhatian bagi kita terhadap keseriusan dalam orientalismenya. Satu sisi yang menarik untuk penulis uraikan dalam tulisan ini, diantara begitu banyaknya hal yang bisa dibahas terkait dengan orietalisme, dengan menggunakan pendekatan kualitatif, deskriptif. Terkait dengan studi orientalis terhadap Islam. Dimana penulis melihat ada beberapa faktor dan dorongan yang menyebabkan salah satu kajian orientalis focus terhadap Islam, baik dipengaruhi oleh faktor sejarah, ideology, politik, kepentingan imperialism, dan murni karena objektifitas ilmu pengetahuan.
\end{abstract}

Kata kunci: Orintalsi, Barat, Islam, Gereja.

\section{A. Pendahuluan}

Secara otomatis tashawur atau yang tergambarkan oleh pikiran dengan istilah orientalisme adalah studi Barat terhadap Timur. Munculnya gerakan tersebut tidak bisa lepas dari faktor yang mempengaruhinya, sehingga upaya tersebut dilakukan. Selama faktor itu masih ada maka studi Barat (Orientalis ) terhadap Timur juga tidak akan pernah bisa dihindari. Akan tetapi akar dari sebuah gerakan ini adalah bagian dari sejarah yang tidak akan bisa terpisahkan antara Islam dan Barat yang sampai hari ini masih mewarnai hubungan antara kedua belah pihak.

Istilah orientalis bukan suatu hal yang tabu lagi dikalangan akademisi, Membahas tentang orientalis berarti membaca kembali sejarah yang pernah terukir antara Timur dengan Barat, serta perkembangannya yang terjadi dari masa ke masa yang sampai hari ini masih tetap berlanjut. Kajian orientalis sendiri memang beragam, mereka 
tidak sama, dan memiliki sudut pandang yang berbeda serta hasil yang berbeda-beda dari hasil telaah mereka terhadap dunia Timur.

Menariknya, keseriusan para orientalis untuk meneliti dunia Timur harus kita acungkan jempol, Muhammad Bahar Akkase dalam tulisanya Orientalis dan Orientalisme dalam Perspektif Sejarah menjelaskan bahwa dalam kurun waktu seratus lima puluh tahun para orientalis sudah berhasil menghasilkan karya penelitian yang mereka terbitkan sekitar enam puluh ribu (60.000) terkait dengan Islam ((Muhammad Bahar Akkase, Orientalis dan Orientalisme dalam Perspektif Sejarah, Jurnal Ilmu Budaya, Juni 2006: 50).

Arina Haqan dalam tulisannya Orintalisme dan Islam Dalam Pergulatan Sejarah, menyimpulkan bahwa adanya gerakan orientalisme ini pada awalnya adalah alat yang digunakan dengan tujuan untuk menjajah negara dan agama Timur, terutama agama Islam. Tetapi seiring perkembangan zaman, gerakan Orientalis pada akhirnya mengalami perubahan-perubahan, dimana sampai dengan saat ini di antara kalangan orientalis sendiri sudah melakukan kajian / studi mereka murni pada kajian ketimuran secara obyektifindependen. Perubahan-perubahan yang terjadi tersebut, telah menggeser perhatian orientalis, tidak hanya terpusat kepada Islam dan umat Islam semata, namun sudah meliputi segala aspek yang berhubungan dengan Timur, baik secara bahasa, budaya, tradisi, adat Istiadat, wilayah, sejarah dan sebagainya. Arina mengelompokkannya menjadi tiga fase yang dilalui kalangan orientalis dalam studi mereka terhadap Timur, yaitu fase sebelum perang salib, perang salib hingga masa pencerahan Eropa, dan periode terakhir dimulai dari masa pencerahan hingga zaman modern.( Arina Haqan, Orintalisme dan Islam Dalam Pergulatan Sejarah, Jurnal, Mutawatir, Vol. 1 No. 2 2011).

Pengaruh pemikiran orientalis hari ini, terutama sekali dalam dunia pendidikan sangat terasa, berdasarkan kepada studi-studi pemikiran orientalis yang marak dipelajari dan menjadi rujukan didalam dunia akademisi, dengan sebuah acuan memenuhi stndar metodologi penulisan karya tulis ilmiah. Menarik memang untuk dibahas, dan aspek-aspek terkait dengan orientlisme juga cukup luas, yang sampai hari ini belum selesai orang-orang melakukan penelitian terhaddapnya. Bahkan sudah menimbulkan reaksi yang sebaliknya, dengan munculnya kajian Timur terhadap Barat, yang dikenal dengan Oksidentalisme.

Diantara aspek-aspek yang mungkin dibahas terkait orientalisme diantaranya adalah aspek sejarah lahirnya orientalsime, seperti penelitian Akkase. Ia menyimpulkan bahwa sulit untuk memastikan kapan dan siapa orang yang pertama kali melakukan studi atau kajian orintalis untuk pertama kalinya (Akkase, Orientalis dan Orientalisme, 2006). Begitu juga dengan arina, yang membahas tentang aspek pergulatan sejarah dan perkembangan orientalisme.

Berbeda dengan apa yang akan penulis sajikan pada penelitian kali ini, dimana titik fokus penulis hanya akan melihat pada bentuk-bentuk studi orientalis kepada Islam, melihat dari latar belakang dan tujuan yang akan 
dicapai dari sebuah studi orientalis terkait dengan Islam.

\section{B. Metode}

Bentuk penelitian ini adalah library research, karena dilihat dari objek penelitiaanya, yang berusaha untuk mengumpukan data-data, dari telaah-telaah pemikiran dan karyakarya orientalis yang sudah ada, sehingga dari data tersebut dapat menggambarkan sebuah perkembangan orintalisme corak dan ragamnya, yang akan dipaparkan dengan metode deskriptif terhadap tulisan dan sumbersumber yang ada. Adapun pola berfikirnya penelitian ini berbentuk pola berfikir induktif, dari data-data yang ada, sehingga dapat ditarik sebuah kesimpulan yang bersifat umum, dari hasil sebuah telaah analitis deskriptif yang dilakukan.

\section{Bahasan}

\section{1) Orientalis dan Oreintalisme Bahasa dan Istilah}

Orientalis atau disebut juga dengan ahli ketimuran (A. Hanafi, Orientalisme Ditinjau Menurut Kacamata Agama 1981:9) dalam bahasa arab berarti Mustasyriq, dan gerakannya disebut dengan orientalisme atau Istisyraq. Dalam kaidah bahasa arab berasal dari kata syaraqa, sebagai contoh: Syaraqat al Syamsu Syarqan, artinya telah terbit matahari dari timur, kemudian mengalami tashrif menjadi Istisyraaq. Secara penggunaan kata orientalis sendiri berasal dari bahasa Prancis yaitu orient yang berarti timur. Orientalis adalah orangnya, sedangkan oerintalisme adalah gerakannya.

Beberapa tokoh mencoba untuk menjelaskan orientalis secara istilah, diantaranya Thaha Amin meurutnya orientalis adalah orang yang melakukan kajian tentang masalah-masalah ketimuran, baik sastra, bahasa, antropologi, sosiologi, psikologi dan agama dengan menggunakan pendekatan Eurocentris (Thaha Hamim, Islam dan $N U$ di Bawah Tekanan Problematika Kontemporer, 2004: 268). M. Ibrahim alfayumy $^{1}$ menurutnya orientalis berarti Setiap orang yang mendalami bahasa orang timur dan peradabannya (M. Ibrhim Fayumy, al Istisyraq Risalatu Isti'mar, 1993:143). Sedangkan orientalisme adalah studi yang difokuskan terhadap Timur Tengah oleh orang Barat (Samy Afify Hijazy, Qadhaya Islamiyah Mua'shirah, 2009:).

Dr. Samy

Afify

menjelaskannya menjadi dua kelompok besar:

a) Studi yang dilakukan oleh Barat yang berhubungan dengan ketimuran, baik dari segi bahasa, adab, sejarah, kepercayaan, syariat, dan peradabannya secara umum.

b) Study akademik yang dilakukan oleh Barat, khususnya para ahli kitab terhadap Islam dan umat Islam dari segala lini, aqidah, syariat, pemikiran, peradaban, sejarah, moral, yang bertujuan untuk merusak dan menanamkan keraguan terhadapa orang Islam dan menyesatkan mereka dari agama Islam. (Samy, 2009: 35)

Penegrtian di atas dapat di kelompokkan menjadi dua bentuk (Samy, 2009:. 38),

\footnotetext{
1. Dekan Fakultas Ushuludin Universitas al Azhar-Kairo tahun 1993.
} 
a) Pengertian umum, yang berarti setiap orang barat yang meneliti tentang ketimuran secara keseluruhan.

b) Pengertian khusus, yang berarti studi Barat yang berhubungan dengan Islam bagian timur, baik dari segi bahasa, adab, sejarah, aqidah, syariat.

\section{2) Awal Pertemuan Islam dan Barat}

Andalusia atau yang kita kenal hari ini dengan nama Spanyol, merupakan pintu yang telah membuka hubungan Islam dengan Barat, dan cikal bakal kemajuan peradaban yang dirasakan oleh Barat pada saat ini, secara khusus dan dunia secara umum. Barat sebelum Islam, merupakan wilayah yang berada dibawah sebuah pemerintahan yang tunduk dibawah pengaruh gereja, dan masyarakatnya hidup didalam pemerintahan tersebut dengan sebuah agama yang disebut Nasrani atau Kristen.

Selama 7 abad Islam berada di Andalusia 755 M - 1492 M, banyak hal yang sudah dihasilkan oleh umat Islam untuk kemajan peradaban umat manusia, Andalusia sudah berubah menjadi sebuah pusat perdaban manusia, disamping Bagdad yang berada di Timur. Berbagai macam ilmu pengetahuan berkembang, dan banyak lahirnya ilmuan-ilmuan yang sampai hari ini jasa mereka masih memberikan sumbangsih terhadap kemajuan dan kemaslahatan kehidupan manuisa modern.

Ibn Bajjah, banyak menulis masalah kedokteran, astronomi dan filsafat. Salah satu karyanya yang fenomenal adalah Hay bin Yaqzhan, yang masih dipelajari sampai hari ini, bagi mereka yang menggeluti filsafat. Ibn Rusyd filosof muslim yang pemikiran-pemikirannya masih dibahsa oleh Barat sampai hari ini. Ahmad ibn Ibas dari Cordova ahli di bidang obat-obatan. Umm al- Hasan bint Abi ja'far ahli kedokteran. Dalam bidang sejarah dan geografi, antaranya adalah Ibn Zubair, Ibn Batuthah dan Ibn Khaldun (Badri Yatim, Sejarah Peradaban Islam, 2008: 102).

Majunya ilmu pengetahuan di dunia Islam, sudah menciptakan sebuah peradaban yang maju di tengah-tengah kehidupan umat muslim, masa-masa ini disebut dengan golden Age-nya Islam, dan dark Age-nya Barat. Perbedaan yang begitu besar memang terlihat pada abad ini, atau yang disebut juga dengan abad pertengahan, pola kehidupan kedua belah pihak memang berbanding terbalik. Tidak hanya pada perkembanga ilmu pengetahuannya, tapi juga sudah pada tatanan kotanya dan bangunanbangunan modernnya. Di lain sisi pada persoalan kebersihan, Barat kala itu masih menjadi persoalan besar.

Kemajuan peradaban yang dimiliki oleh Islam, melahirkan ketertarikan yang begitu besar bagi masyarakat Barat untuk dapat belajar kepada umat Islam. Akan tetapi ketertarikan tersebut tidak serta merta bebas bagi siapa saja untuk belajar dan mengambil ilmu dari umat Islam.Ppada awalnya, hanya terbatas untuk kalangan gereja, mereka belajar bahasa Arab, dan studi naskah yang dimiliki oleh 
umat Islam. Tidak ada kendala yang begitu berarti yang dihadapi oleh Barat untuk dapat belajar dari Umat Islam, karena umat Islam mebukakan pintu selebar-lebarnya bagi siapa saja yang ingin menimba ilmu, bahkan tidak sampai di situ, semua fasilitas yang ada juga dapat dinikmati oleh siapapun, baik dari kalangan non muslim sendiri.

Apa yang mereka dapatkan dari umat Islam dibawa pulang, serta karya-karya yang berbahasa arab diterjemahkan kedalam bahasa latin dan mereka pelajari, sampai pada akhirnya mereka mampu untuk mendirikan sekolah-sekolah bahkan universitas-universitas.

Bukan tanpa alasan adanya sebuah upaya pembatasan yang dilakukan untuk dapat belajar kepada umat Islam. Tidak bisa dipungkiri, bahwa adanya kekhawatiran pada masa itu terhadap pengaruh Islam sebagai agama damai dan maju yang semakin besar masuk ketengahtengah pemikiran dan pandangan masyarakat Barat yang melihat adanya kebebasan dan kemerdekaan di dalamnya serta jaminan kehidupan yang dirangkum Dharuriyatul Khamsah ${ }^{2}$.

Pada saat yang bersamaan, perkembangan Islam begitu pesatnya, jauh menjangkau keluar batas wilayahwilayah Islam, ke daerah dimana pada awalnya merupakan basis Gereja (M. Abdul Karim, Sejarah Pemikiran dan Peradaban Islam, 2012: 228-229), meski Islam tidak memeranginya melalui perang senjata dan memaksa orang untuk masuk Islam. Keadaan ini

2. Penjagaan terhadap agama, akal, harta, kehormatan dan keturunan. sudah menggeser pengaruh gereja, karena masyarakat sudah mulai meragukan keberadaan gereja yang selama ini mereka hidup dibawah pengaruhnya. Reduplah pengaruh gereja yang selama ini telah menjadi legitimasi untuk sebuah kekuasaan. Hancurlah sistem theokrasi dalam struktur kehidupan Barat yang telah berlansung berabad-abad (Dr. Thariq Suwaydan, "al Andalus Tarikh al Mushawar”, PDF).

\section{3) Lahirnya Studi Orientalis}

Menurut Arbery istillah orientalis baru dipakaikan pada tahun 1630 M (Fayumy, al Istisyraq:142), akan tetapi belum bisa dijelaskan awal munculnya orientalis secara pasti, karena munculnya orientalis ketengahtengah kehidupan ini disebabkan karena faktor sejarah dan kondisi yang terus berkelanjutan, meskipun ada beberapa pendapat mencoba untuk menjelaskan kapan munculnya orientalis, diantaranya:

a) Berawal pada abad 12, setelah al-Quran diterjemahkan kedalam bahasa Latin.

b) Munculnya pada abad ke 13, ketika berkecamuknya perang Salib sejak 1097-1295 M.

c) Ketika Islam mulai membuka jendela ke Barat melalui Andalusia/ Spanyol, dimana para pendeta dan pelajar-pelajar

\footnotetext{
${ }^{3}$.Dr. Ibrahim Fayumy dalam bukunya al Istisyraq wa Risalatu Isti'mar" hlm. 188, menerangkan awal permulaan berkembangnya orientalis untuk pertama kalinya ditandai dengan diterjemahkannya al Quran kedalam bahasa Latin, dibawah perintah pendeta Petros Apiles tahun 1143 M di Spanyol.
} 
Barat banyak yang berdatangan dan belajar dari umat Islam. (Samy, Qadhaya: 40-41).

Kuat dugaan,

awal pekembangan orientalis itu sendiri berawal dari interaksi yang terjadi antara Barat dengan Umat Islam di Andalusia, keberadaan umat Islam disana adalah awal dari persentuhan Barat dengan ilmu pengetahuan yang bersifat rasional yang sudah berkembang di dunia Islam, dimana perkembangan pemikiran di Barat sebelumnya lebih dominan diwarnai oleh pengaruh kekultusan ajaran agama.

Adanya persentuhan Islam dengan Barat ini, merupakan titik awal perhatian Barat terhadap Islam, yang pada akhirnya melahirkan perhatian bagi masyarakat Barat untuk meneliti tentang Islam lebih jauh, walau dengan motif dan motifasi yang berbeda-beda. Melihat dari perkembangan waktu dan motifasi yang ada, dapat dijelaskan bahwa studi yang dilakukan oleh Barat terhadap Islam secara khusus, dan Timur secara luas, pada awalnya berangkat dari sebuah kekhawatiran terhadap pengaruh Islam yang semakin besar masuk ke Barat (Samy Qadhaya: 46).

Thaha Hubaysyi menyebutkan terjadinya perubahan tersebut di tengah-tengah masyarakat Barat setelah mereka mengenal Islam sangat dipengaruhi oleh beberapa hal berikut:

1. Aspek masa lalu.

Dimana dalam keilmuannya Barat sangat jauh ketinggalan yang disebabkan oleh pertentangan antara ilmu dan agama. Dalam masalah ekonomi rakyat dimana rakyat kecil tidak memiliki kebebasan dalam harta, dan kemiskinan meraja lela, serta penindasan. Dalam aspek kesehatan mereka masih percaya kepada ramalanramalan.

\section{Aspek agama}

kebebasan yang direbut oleh gerejagereja, doktrin doktrin agama, tidak adanya kebebasan berfikir sehingga timbulnya pertentangan antara gereja dan umatnya.

\section{Aspek Politik}

Dengan berkembangnya daerah kekuasaan Islam dan makin sempitnya daerah yang dikuasai oleh Gereja. (Thaha Hubaysyi, Tayarat wa al Madzahib al Mu'ashirah Tahlilun wa rududun: 28).

Barat secara umum, bersyukur dengan hadirnya Islam, karena sudah membukakan bagi mereka jalan untuk mencapai sebuah kemajuan, yang selama ini belum mereka rasakan, akan tetapi, di lain sisi Islam juga menjadi momok yang menakutkan bagi sebagian kalangan, terutama bagi Gereja.

Kondisi ini semakin diperparah dengan berbagai macam kekalahan yang dialami oleh pasukan Salib terhadap umat Islam dalam perang salib, yang menambah catatan kelam Gereja terhadap umat Islam, dalam upaya mereka untuk mengambil wilayah-wilayah yang sudah dimiliki oleh umat Islam, dan mengembalikan pengaruh-pengaruh mereka di tengah-tengah masyarakat, baik secara ideology dan politik. 
Berawal dari rasa keingintahuan untuk belajar lebih jauh dari umat Islam agar mencapai sebuah kemajuan peradaban, pada akhirnya berubah menjadi sebuah upaya untuk menghambat pengaruh Islam masuk kedalam tubuh masyarakat Barat, untuk mengembalikan kepercayaan masyarakat terhadap Gereja. Langkah-langkah offensive pernah dicoba melalui perang terbuka yang dilancarkan terhadap Islam, melalui Imperialisme penjajahan, dan studistudi (orientalisme) tentang Islam denagn tujuan memberikan informasi-informasi yang keliru tentang Islam dan mencari-cari letak kelemahannya. Yang dikembangkan melalui sebuah sebuah framing pemberitaan dan media-media untuk menciptakan mindset negative terhadap Islam ditengah-tengah kehidupan masyarakat Barat. Melalui mindset yang sudah tertanam dalam pikiran seseorang dengan framing yang digambarkan diharapkan mampu, untuk menghentikan pengaruh Islam.

Langkah-langkah yang mereka terapkan untuk menjalankan misi ini (Thaha Hubaysyi, Tayarat: 42-43):

1. Mempelajari bahasa Arab.

2. Berusaha memiliki manuskripmanuskrip yang dimiliki oleh Islam, dan memanfaatkan untuk kepentingan mereka.

3. Menghilangkan sisi positif yang ada dalam Islam dari kajiankajian mereka.

4. Mencari celah kelemahan serta kekurangan yang ada dalam Islam, sehingga menjauhkan mereka dari nora-norma dan ajaran Islam.
5. Memanipulasi sejarah, agar umat Islam tidak mengenal lagi sejarah mereka.

6. Menimbulkan rasa kesukuan dalam diri umat Islam atau rasa fanatisme terhadap golongan, menciptakan sekte- sekte ${ }^{4}$ agar umat Islam terpecah belah. Dengan begitu umat Islam akan lemah dengan sendirinya.

7. Menyebarkan Islamopobhia di dalam kalangan Barat.

8. Menerapkan hukum-hukum buatan manusia.

Dapat dipahami pada dekade awal, studi Barat tentang Islam lebih dominan berasal dari kalangan gereja, yang ber-orientasi kepada strategi Defensive untuk dapat mempertahankan diri dan kristenisasi ${ }^{5}$

4. Contoh:Seperti yang terjadi di India dengan munculnya golongan Ahmadiyah dengan tokohnya Mirza Ghulam Ahmad, yang dibantu pendanaannya oleh Inggris untuk melemahkan semangat juang kaum Muslimin.

5. Istilah kristenisasi sendiri dalam Islam memiliki dua istilah, yang pertama adalah Tabsyir dan yang kedua adalah Tanshir, keduanya memiliki maksud dan tujuan tersendiri. IIstilah Tabsyir sendiri menurut Dr. Samy Afify dalam bukunya Qadhaya Islamiyah Mu'ashirah “ institusi-institusi Kristen yang berdiri atas ajaran Kristen yang bertugas untuk menyebarkan ajaran Injil, mengajak manusia secara keseluruhan untuk masuk agama Kristen terutama sekali orang Muslim”. Adapun Tanshir menurut syeikh Ibrahim Ukasyah sebagaimana dikutip oleh Dr. Husain Muhammad Mahmud Abdul Muthallib dalam bukunya al Tanshir Haqiqatuhu wa Thariqu Muwajahatuhu “ sekelompok misionaris bekerja untuk menguasai suatu daerah tertentu, dan bekerja untuk mengkristenkan penduduknya, dan mendirikan gereja setempat serta memberikan sokongan dana untuk orang yang mau bergerak didalamnya dan 
untuk menghentikan pengaruh Islam, Dr. Ibrahim al Fayumy menyimpulkan secara garis besar orientalis dalam bentuk ini gerakannya mempunyai tiga konsep utama: ( Qadhaya: 39.)

1. Kristenisasi.

2. Imperialisme perang salib dalam skala internasional,

3. Mengupayakan segenap kemampuan untuk perang pemikiran.

Peter the Venerable, salah satu pendeta dan juga orientalis yang hidup dari 1094-1156M, melakukan sebuah perjalanan ke Spanyol Utara. Diantara tujuan perjalannya adalah untuk menggali informasi yang akurat tentang Islam dan umatnya, dari informasi tersebut diharapkan mampu menepis anggapan apapun dari umat Kristen tentang Islam. Informasi dan data-data yang didapatkan dikumpulkan, serta buku-buku Ia terjemahkan ke dalam bahasa Latin. Terjemahan itu nantinya digunakan oleh misionaris-misionaris terhadap dunia Islam.( Adnin Armas, Metodologi Bibel dalam Studi AlQur'an, Jakarta: 2005).

Sebuah ungkapan yang terkenal dari Peter kepada orang Islam, "But I attack you not, as some of us [Christians] often do, by arms, but by words; not by force, but by reason; not in hatred, but in love"
Artinya:
"aku
menyerangmu, bukan sebagaimana sebagian dari kami [orang-orang Kristen] sering melakukan, dengan

menyebarkan agama Kristen ke daerah lain yang belum dikristenkan. (terj, pen). Hlm. 9 . senjata, tetapi dengan kata-

kata, bukan dengan kekuatan, namun dengan pikiran; bukan dengan kebencian, namun dengan cinta".

Hal ini berdasarkan kepada strategi yang digunakan oleh peter dalam mengahdapi umat Islam. Dimana ia berpendapat, bahwa menaklukkan Islam tidak cukup hanya dengan perang, akan tetapi juga harus bisa membaptis pemikiran pemikiran mereka.

Kerja keras yang diusahakan selama ini bisa dikatakan sudah membuahkan hasil, hal ini dapat dilihat dari studi yang dilakukan oleh Barat tentang Islam yang tidak hanya dilakukan oleh kalangan gereja semata, akan tetapi sudah dilakukan oleh berbgai macam kalangan yang berbeda, dengan rasa yang sama, untuk mencaricari kelemahan Islam, dan kejelakannya, sekalipun belum kenal dengan Islam.

Masuknya framing Islam kedalam mindset berbagai kalangan belakangan ini, tidak mungkin akan lahir dengan sendirinya, hal itu terwujud jika ada informasi yang disampaikan tentang Islam sesuai dengan framing dan mindset yang dikembangkan.

Diantara hasil yang negatif dari pemikiran mereka, seperti pemikiran Goldseiher yang mengatakan bahwa Islam itu tidak bisa menerima perubahan, Nabi Muhammad adalah muridnya orang Yahudi, Islam adalah rekayasa Muhammad Saw, dan banyak menafsirkan ayat-ayat al-Quran yang tidak sesuai dengan maksud dan 
tujuanya (Abdul Jalil Syalaby, al Islamu wa al Mustasyriqun: 46)

Studi terhadap Islam tidak hanya menggambarkan Islam sebagai ancaman bagi Barat saja, akan tetapi sebuah framing yang dikembangkan bahwa Islam adalah ancaman bagi kedamaian dunia, terutama hubungannya dengan isu teroris yang selalu dihubung-hubungkan dengan Islam melalui studi-studi yang dilakukan.

Salah satu tokoh orientalis dalam bukunya The Middle East: A Brief History of the Last 2000 Year bernard Lewis menuliskan :

"....But unlike the jihad it was concerned primarily with the defense or reconquest of threatened or lost Christian territory...The Muslim jihad, in contrast, was perceived [by Muslims] as unlimited, as a religious obligation that would continue until all the world had either adopted the Muslim faith or submitted to Muslim rule.... The object of jihad is to bring the whole world under Islamic law". (Bernard Lewis, The Middle East: A Brief History of the Last 2000 Year, 2006: 233234).

Artinya: Berbeda dengan jihad, yang memang tujuan utamanya adalah mempertahankan atau penaklukan wilayah Kristen. Jihad seorang Muslim merupakan bagian yang tak terbatas, sebagai sebuah perintah agama yang tidak akan pernah berhenti sehingga seluruh dunia mengadopsi aturan Islam atau berada dibawah kekuasaan Islam.

Dalam tulisannya yang lain didalam bukunya What went Wrong" Lewis menjelaskan, kemunduran, kebodohan dan keterbelakangan yang terjadi dalam umat Islam hari ini, itu disebabkan oleh banyak faktor dan pemikiran, hal itu jugalah yang menyebabkan terjadinya serangan terhadap WTC 11 september 2001. Dalam buku ini lewis menggambarkan perbandingan antara kemunduran dan kemajuan yang diperoleh Barat pada hari ini, yang kuat dan modern . (Lewis, What Went Wrong, 2002, bab 7: 113). Disini Lewis membenarkan bahwa tragedy WTC adalah ulah umat Islam karena kemarahannya.

Dilain sisi Samuel $P$. Huntington menuliskan "The rhetoric of America's ideological war with militant communism has been transferred to its religious and cultural war with militant Islam", dan "The twentieth-century conflict between liberal democracy and MarxistLeninism is only a fleeting and superficial historical phenomenon compared to the continuing and deeply conflictual relation between Islam and Christianity."( Israr Hasan, Believers and Brothers : a History of Uneasy Realationship, 2009:160).

Dalam buku Qadaya Islamiyah ruang gerak yang dimanfaatkan oleh para orientalis seperti ini: (Samy, Qadhaya Islamiyah, :47 -56)
1. Ruang lingkup pendidikan lembaga-lembaga pendidikan seperti universitas-universitas dikawasan timur yang bekerja untuk kepentingan mereka. 
2. Mengumpulkan dan mendalami manuskrip-manuskrip Islam yang penuh dengan nilai-nilai keilmuan dan kemajuan.

3. Melakukan penerjemahan terhadap buku Islam dengan pemahaman-pemahaman yang sesuai dengan keinginan mereka, yang bertentangan dengan ajaran Islam.

4. Mencetak buku, baik itu dalam bentuk bahasa Arab ataupun bahasa Inggris dan Latin tentang keIslaman dari segala aspeknya, oleh penulis-penulis mereka.

5. Mengadakan kajian-kajian ilmiyah dan muktamarmuktamar tentang keislaman, yang bertujuan untuk berbagi berita dan pengalaman antara para orientalis, serta topiktopik baru tentang Islam.

Ruang gerak orientalis dalam upaya mengembangkan pemikirannya terhadap Islam banyak melalui karya tulis dan pendidikan, itu dapat dirasakan dibangku-bangku sekolah hingga perguruan tinggi. Sedangkan untuk menerobos masuk kedalam tatanan masyarakat bawah mereka mengunakan media komunikasi, televisi, dan perfileman.

Lain dari pada itu, Studi orientalis juga sangat berfungsi untuk membantu kolonialisme untuk mencari titik lemah umat Islam, sehingga duniadunia Islam mudah ditaklukan. Sebagaimana studi yang pernah dilakukan oleh snoug hogronje, yang menyamar sebagai seorang muslim, untuk meneliti tentang kekuatan Umat Islam, dan hasil penelitiannya tersebut diserahkan kepada pihak belanda untuk mengatur strategi dalam melemahkan perlawanan umat Islam.

Snouck Hurgronje seorang orientalis yang menyamar sebagai seorang muslim dan ditugaskan di Indonesia oleh kerajaan Belanda menerbitkan bukunya Nederland en de Islam, yang berisi pemikiran dan strategi cara menghadapi Islam :

(1) Dalam bidang yang murni agama, pemerintah dan pejabat-pejabatnya harus menjamin dan memelihara kebebasan mutlak,

(2) Dalam bidang politik, kebebasan itu harus dibatasi 'untuk kepentingan bersama',

(3) Dalam bidang hukum Islam, pemerintah harus menjauhi intervensi yang dipaksakan, sekalipun harus mendorong ke arah proses evolusi hukum sebanyak mungkin,

(4) Garis-garis kebijaksanaan yang kurang lebih negatif ini harus menuju ke arah tujuan yang positif, yaitu kemajuan orang-orang Islam yang harus dibebaskan dari beberapa "peninggalan ajaran abad pertengahan yang tidak berguna yang menyeret mereka hingga demikian lamanya" agar supaya dengan jalan ini - dengan perantaraan pendidikan dan pengajaran - dapat memperoleh kesempatan "asosiasi" kultural dengan kebudayaan Barat. (Mukti Ali, Ilmu Perbandingan Agama di Indonesia, 1998: 32).

Tidak salah Dr. M. Ibrahim Fayumi Mengutip dari kitab Istisyraq karangan Edward Said dalam bukunya al Istisyraq wa Risalatu Isti'mar, adalah sebuah istilah Barat untuk mengontrol Timur dan menguasainya.(Fayumy, al Istisyraq:141). 
Sentuhan ilmu pengetahuan yang terus berkembang ditengahtengah masyarakat Barat, telah membawa sebuah perubahan besar, yang mebawa Barat- dari satu fase kepada fase yang lain. Fase pra Islam, dimana Barat masih berada dibawah pengaruh Gereja yang begitu dominan, kedua adalah ketika pengaruh Islam masuk ke dunia Barat, ketiga, beralih pada fase Renaincense, yang pada akhirnya diwarnai dengan sekulariseme dan liberalism, bahkan sampai kepada sebuah pandangan hidup yang atheism, yang secara tidak lansung mengakhiri dominasi agama di tengah-tengah kehidupan masyarakat Barat itu sendiri. Adanya perubahan fase tersebut, juga mempengaruhi terhadap studi Barat tentang Islam.

Sebagaimana yang kita sebutkan di atas, bahwa Orientalis dalam perjalanannya juga mengalami perkembangan yang menimbulkan kelompok-kelompok dalam diri orientalis sendiri, tidak hanya sebatas kebencian dan mencari celah untuk merusak Islam dan Umatnya, namun ada yang berdasarkan keinginan pribadi, dan keinginan untuk mencari kebenaran sesuai dengan tanggung jawab ilmiah. Maka hari ini kita mendapati orientalis tidak hanya memiliki satu ragam atau mazhab dalam menjalankan studinya tentang keIslaman dan ketimuran, dapat dikelompokkan menjadi:

1. Kelompok yang suka membuatbuat cerita, kebanyakan tidak bergerak dalam bidang keilmuan, dan menilai Islam sesuai dengan kebohongan mereka.

2. Kelompok yang bekerja untuk kemajuan barat, baik dari segi ekonomi, politik, dan imperialisme.

3. Kelompok yang mengatas namakan diri mereka dengan kajian ilmiyah, akan tetapi menyelewengkan fakta yang sebenarnya, dan menenamkn keraguan terhadap ajaran Islam.

4. Kelompok yang benar-benar mengkaji Islam secara ilmiyah dan objecktif, bahkan banyak dari mereka yang masuk Islam.

5. Kelompok orientalis yang hanya fokus dalam pembelajaran bahasa Arab saja.(Afify, Qadhaya :53-54)

Dibalik kebohongan yang diciptakan, ada beberapa karya dari orientalis yang bisa kita manfaatkan, walaupun tidak banyak, namun bisa memberikan sumbangsih besar terhadap kita umat Islam, diantaranya adalah karangan Karl Broclaman, dengan judul Tarikhul Adab al A'raby, yang menjadi kitab standart dalam bidang studi Arab dan ke Islaman. Selain itu juga ada karangan orientalis yang lain yang berjudul al Mu'jam al Mufahras li Alfhazhil Hadis al Syarif (Samy, Qadhaya: 54), yang dapat kita manfaatkan dalam meneliti hadis. Dari pergerakan orientalis hingga hari ini, menunjukkan kepada kita akan kebenaran ayat Allah Swt, dalam surat al-Baqarah, 2: 120 yang artinya :

"Tidak akan pernah ridha (terhadap engkau wahai Muhammad) baik orang Yahudi ataupun Nasrani sehingga kamu mengikuti ajaran mereka." 
Melihat dari perkembangannya, kajian orientalsi menjadi sebuah bidang ilmu yang memang telah sempurna itu terjadi pada akhir abad ke $18 \mathrm{M}$, dimana disana mereka telah mengkaji tentang peradaban Timur secara keseluruhan, naik secara materilnya, ruhiyahnya, ekonomi, sejarah, letak geografinya, politik, kebudayaan, filsafatya dan lain-lain. Melihat dari fenomena ini terjadi perkembangan dalam diri orientlis sendiri, sehingga munculnya orientalis yang berpandangan objektif terhadap timur dan mencari kebenarannya (al Istisyraq: 170). Sebagian ulama menyebut kelompok seperti ini adalah Almusta'rib ${ }^{6}$.

\section{Kesimpulan}

Dapat dipahami yang paling mendasari munculnya gerakan orientlis pada awalnya adalah aspek masa lalu yang curam dan bentuk persaingan antara gereja Kristen terhadap Islam terutama di Andalus (Spanyol), termasuk aspek politik dan juga faktor strategi perang salib yang merubah haluan kepada studi-studi Islam. Jadi secara garis besar faktor utamanya adalah agama, ideologi dan politik. Berawal dari kekhawatiran gereja jika harus kehilangan eksistensi agama dari umatnya sendiri, dan bagaimana bisa menarik orang-orang kembali kepada keyakinan sebelumnya.

Perekembangan berikutnya, studi oreintalis terhadap Islam sangat bermanfaat bagi kepentingan empiarialisme Barat terhadap dunia Timur, terutama dunia Islam., seperti

\footnotetext{
${ }^{6}$.Orang Barat yang mengkaji secara benar tentang ketimuran dan Islam melalui literartur-literatur Timur dan Islam.
}

studi Snouck Hurgronje di Indonesia. Dalam perkembangannya, orientalis juga muncul dari kalangan yang beragama Yahudi, seperti Bernard Lewis, Goldshiher dan lain-lain. Adapun orientalis dari kalangan Yahudi, mereka bekerja untuk menebarkan paham, serta misinya sendiri. Namun pada satu sisi mereka bisa bersama, yang paling mencolok dari pola gerakan mereka saat ini adalah framing Islam dengan wajah teroris, yang digambarkan sebagai ancaman global.

Studi-studi orientalis ini tidak hanya ditujukan untuk membentengi Barat dari pengaruh Islam, namun juga sebaliknya ditujukan kepada umat Islam, berbentuk upaya pendangkalanpendangkalan aqidah, serta informasiinformasi yg keliru tentang Islam, baik dari sisi sejarah, pemikiran dan worldview, serta menjauhkan umat Islam jauh dari agamanya, dan phobia antar sesama mereka.

Akan tetapi terjadinya fase perkembangan-perkembangan

pemikiran di Barat, studi terhadap Islam juga mengalami perkembangan, tidak hanya dilakukan oleh kalangan gereja semata, dan juga tidak selalu untuk menyerang Islam, namun sudah melahirkan orientalis-orientalis yang benar-benar berusaha untuk objective, dan sebagian dari hasil penelitian mereka juga dapat kita manfaatkan dan memberikan sumbangsih terhadap Islam. Wallahu A'lam. 


\section{Daftar Kepustakaan}

Ali, Mukti. Ilmu Perbandingan Agama di Indonesia, Bandung: Mizan, 1998

al Fayumy, M. Ibrahim, al Istisyraq: Risalatu Isti'mar, Kairo : Darul Fikri, 1993.

Akkase, Muhammad Bahar. Orientalis dan Orientalisme dalam Perspektif Sejarah, Jurnal Ilmu Budaya, vol. 4. No. 1. Juni 2016,

Armas, Adnin. Metodologi Bibel dalam Studi Al-Qur'an, Jakarta: GIP, 2005.

Hamim, Thaha. Islam dan $N U$ di Bawah Tekanan Problematika Kontemporer, Surabaya: Diantama, 2004.

Hanafi, A. Orientalisme Ditinjau Menurut Kacamata Agama :Quran dan Hadits, Jakarta: Pustaka al Husna, 1981.

Hasan, Israr. Believers and Brothers : a History of Uneasy Realationship, Bloomington: Authorhouse, 2009.

Haqan, Arina. Orintalisme dan Islam Dalam Pergultan Sejarah, Jurnal, Mutawatir, Vol. 1 No. 22011.
Hijazy, Samy A'fify. Qadhaya Islamiyah Mu'ashirah Hawla al Islam wa al Fikru al A'lamy, Kairo : Maktabah Risywan, 2009.

Hubaysyi, Thaha. al Tayarat wa al Madzhib al Mua'shirah: Tahlilun wa Rududun, Kairo : Maktabah Iman, 2011.

Karim, M. Abdul, Sejarah Pemikiran dan Peradaban Islam, Yogyakarta: Bagaskara, cet. IV, 2012.

Lewis, Bernard. The Middle East: A Brief History of the Last 2000 Year, New York: Scripner, 2006. Oxford University Press, 2002.

Muthallib, Husain M. Mahmud Abdul, al Tanshir: Haqiqatuhu wa Thuruqu Muwajahatihi, Kairo : Maktabah Iman, 2010.

Suwaydan, Thariq. "al Andalus Tarikh al Mushawar", PDF

Syalaby, Abdul Jalil. al Islamu wa al Mustasyriqun, Kairo : Mathba'ah Sya'ab,

Yatim, Badri. Sejarah Peradaban Islam, Jakarta: PT Raja Grafindo Persada, 2008. 